J. Product. \& Dev., 19(3):237-252 (2014)

\title{
EFFECT OF FOLIAR SPRAY TREATMENTS WITH SOME NATURAL EXTRACTS ON PRODUCTIVITY AND FRUIT QUALITY OF STRAWBERRY UNDER SANDY SOIL CONDITIONS
}

\author{
R.M.M. Yousef ${ }^{1}$ and E.E. Abou El-Khair ${ }^{2}$ \\ ${ }^{1}$ Medicinal and Aromatic Plants Res. Dept., Hort. Res. Inst., Agric. Res. \\ Center Egypt. \\ ${ }^{2}$ Potato and Vegetatively Propagated Vegetables Res. Dept., Hort. Res. Inst. \\ Agric. Res. Center Egypt.
}

\section{ABSTRACT}

This experiment was carried out during the two seasons of 2011/2012 and 2012/2013 at a Private Vegetable Farm in ElKassasein distract, Ismailia Governorate, Egypt, to investigate the effect of foliar spray with some natural material extracts (cinnamon, chili pepper, henna and turmeric at 1 or $2 \mathrm{~g} /$ liter of each) beside control treatment (foliar spray with water only) on some physiological, chemical measurements, yield and its components and fruit quality of strawberry plants $c v$. Festival grown in sandy soil and using drip irrigation system.

The obtained results can be summarized as follows: Spraying plants with henna or turmeric extracts $2 \mathrm{~g} / \mathrm{l}$ of each had significant effect on plant height, number of leaves/ plant, shoot dry weight, total chlorophyll in leaves, $N, P$ and $K$ contents and their uptake by shoots, early and total yield/fed., average fruit weight as compared to the other foliar treatments or control in both seasons. Moreover, spraying strawberry plants with turmeric extract at $2 \mathrm{~g} / \mathrm{l}$ recorded the highest values of all abovementioned traits, total sugars and anthocyanin content in fruit in both seasons. In addition, spraying plant with henna extracts at $2 \mathrm{~g} / \mathrm{l}$ recorded the highest fruit firmness in both seasons, nevertheless the maximum vitamin $C$ was obtained with plants received $2 \mathrm{~g} / \mathrm{l}$ chili pepper extract in both seasons.

Conclusively, from the foregoing results of this study, it could be concluded that spraying strawberry plants with henna or turmeric extracts $2 \mathrm{~g} / \mathrm{l}$ of each four times beginning 60 days from 
transplanting and 15 days intervals were the best treatments for increased plant growth, total yield and fruit quality of strawberry under sandy soil conditions.

Key words: Strawberry, natural extracts, cinnamon, chili pepper, henna, turmeric extracts, yield and fruit quality.

\section{INTRODUCTION}

Strawberry (Fragaria $x$ ananassa Duch.) is a small fruit crop of great nutritional and medicinal values (Maas et al., 1991) and is one of the most popular fruits worldwide. In the last two decades, strawberry has become one of the very important horticultural vegetable crops for local fresh consumption, food processing and for export, in Egypt. Strawberries are unique with highly desirable taste, flavor, and excellent dietary sources of ascorbic acid, potassium, fiber and simple sugar sources of energy (Perez et al., 1997). Crop yield and early harvests are of utmost important target for growers, moreover fruit quality is a considerable important to the consumers.

Natural extracts from cinnamon bark, chili pepper fruit powders, henna leaf and turmeric rhizome have been used traditionally as medicine throughout the world from ancient times. Recently, public health and environmental safety concerns encouraged the use of these natural products as a complete replacement of chemicals for improving growth, nutritional status of the plant and its production. And also for their positive action on controlling pests for their synergistic effects on growth and mortality of most fungus.

Foliar sprays of some plant extracts on strawberry plants has recently received apparent interest. The various positive effects of applying active plant extracts were attributed to its contents of different nutrients, vitamins, hormones, natural plant growth regulators.

Cinnamon (Cinnamo mumverum) Cinnamon contains proteins, carbohydrates, vitamins ( $\mathrm{A}, \mathrm{C}, \mathrm{E}$ and $\mathrm{B}_{3}$ ), minerals like $\mathrm{Ca}, \mathrm{Fe}, \mathrm{Mg}, \mathrm{Mn}, \mathrm{P}$ and Zn (Vangalapati et al., 2012). The cinnamon is having essential oil, cinnamic acid, cinnamaldehyde and cinnamate and also cinnamon is high in antioxidants activity (Jakhetia et al., 2010). In this regard, Slim (2014) found that foliar sprays with extracts of roselle and cinnamon significantly increased dry weight of leaves, leaf potassium content, TSS, TSS/acid ratio, ascorbic acid content and reduced juice total acidity as compared with control of Valencia orange trees. 
Capsaicin (8-methyl-N- vanillyl-trans -6-nonenamide, $\mathrm{C}_{18} \mathrm{H}_{27} \mathrm{NO}_{3}$ ) is an active component of chili pepper fruit and contain nitrogen element. Chili pepper fruit powder contains $\mathrm{Fe}, \mathrm{Mn}, \mathrm{Mg}, \mathrm{P}, \mathrm{Zn}$ and $\mathrm{Se}$, vitamins (vitamin $\mathrm{B}_{6}$, vitamin $\mathrm{B}_{2}$ and vitamin $\mathrm{C}$ ) and $\mathrm{B}$-carotene.

Lawsonia inermis (henna) belongs to the family Lythreaceae and the sole member of its genus Lawsonia. Henna leaf powder contains $\mathrm{Ca}, \mathrm{Na}, \mathrm{P}$ and $\mathrm{K}$ ranging from 0.2 to $4 \%$. The $\mathrm{Mg}$ content was less than $2 \%$, while $\mathrm{Cu}, \mathrm{Zn}$ and Fe contents were above $0.5,1.1$ and $15 \%$, respectively, Mn content was less than $1.5 \%$ while $\mathrm{N}$ content was less than $1.5 \%$ ( Zumrutdal and Ozaslan, 2012). A wide range of compounds has been reported from $L$. alba, including coumarins, xanthones and flovonoids (Nizam et al., 2013). Lawsone $\left(\mathrm{C}_{10} \mathrm{H}_{6} \mathrm{O}_{3}\right)$ is the active ingredient. In this concern, Chandrasekaran et al. (2000) found that soyabean seed treatment with henna leaf extract at $10 \%$ significantly increased shoot length. Pathak and Srivastava (2000) stated that the total phenols content in sunflower was maximum after treatment with henna extract. Hanafy et al. (2012) found that the highest dry weight of leaves/plant, leaf area, total carbohydrates and $\mathrm{N}$ contents in leaves of Schefflera arboricola were obtained with garlic extract followed by yeast extract, then aloe extract and finally henna extract in the two seasons.

Turmeric (Curcuma longa L). is a herbaceous perennial plant belonging to the Zingiberaceous family. Turmeric is contain yellow compounds called curcuminoids $(5 \%)$ and volatile oil $(6 \%)$ which were active components, and also contain anti-free radical , anti-fungi and antibacteria activities ( Banerjee and Nigam, 1978; Ruby et al., 1995). The curcuminoids are natural phenols that are responsible for yellow color of turmeric. In this regard, Ahmed et al. (2013) indicated that foliar spray of orange trees with turmeric extract at $0.1 \%$ was significantly increased leaf area as well as $\mathrm{N}, \mathrm{P}, \mathrm{K}, \mathrm{Mg}$, total chlorophylls and total carotenoids in the leaves in relative to the control treatment. Also, Ahmed et al. (2014) showed that, the best results with regard to yield and fruit quality of Keitte mango trees were obtained due to spraying the trees three times with turmeric extract $(0.1 \%)$ plus salicylic acid (100 ppm) as compared to onion oil, garlic oil and green tea extract.

Therefore, the aim of the present study is to investigate the effects of some natural extracts of cinnamon, chili, henna and turmeric on growth, leaf chemical constituents, fruit yield and quality of strawberry plant grown under sandy soil conditions and drip irrigation system. 


\section{MATERIALS AND METHODS}

This experiment was carried out during two successive winter seasons of 2011/2012 and 2012/2013 at a Private Vegetable Farm in EL-Kassasein Region, Ismailia Governorate on Festival strawberry cultivar. It indicated to study the effect of foliar spray with some natural extracts of cinnamon, chili, henna and turmeric on growth, leaf chemical constituents, yield and its quality under sandy soil conditions and drip irrigation system. The physical and chemical properties of experimental soil in the two seasons showed that it was sandy in texture and had 0.07 and $0.08 \%$ organic matter, 8.11 and $8.09 \mathrm{pH}, 1.99$ and $1.84 \mathrm{mmhos} / \mathrm{cm} \mathrm{EC,} 4.74$ and $4.92 \mathrm{ppm}$ available N, 3.53 and 3.49 ppm available $\mathrm{P}$ and 9.53 and $9.58 \mathrm{ppm}$ available $\mathrm{K}$, respectively.

This experiment included nine treatments, i.e., foliar spray with extracts of cinnamon bark, chili pepper fruit, henna leaf powders and turmeric rhizome at 1 and $2 \mathrm{~g} / \mathrm{l}$ water of each as well as control treatment ( sprayed with water). Cinnamon bark, chili pepper fruit, henna leaf powder and turmeric rhizome at 1 and $2 \mathrm{~g}$ each were diluted in one liter water and left to soak for one hour, then the contents were filtered and the final volume of extracts were completed with water to one liter

Fresh transplants of Festival cultivar were obtained from local nursery and dipped in $0.2 \%$ Rhizolex solution as fungicide for 20 minutes before planting. The planting distance was $25 \mathrm{~cm}$ between transplants in both sides of the dripper line and was done on September $19^{\text {th }}$ and $18^{\text {th }}$ during the $1^{\text {st }}$ and $2^{\text {nd }}$ seasons, respectively. These treatments were arranged in a randomized complete block design with three replicates. The plants were sprayed into four times beginning 60 days after transplanting with 15 days intervals.

The experimental unit area was $12.6 \mathrm{~m}^{2}$. It contains three dripper lines with $6 \mathrm{~m}$ length each and $70 \mathrm{~cm}$ distance between the two drippers lines. One line was used to measure the morphological and physiological traits and the other two lines were used for yield determinations. In addition, one row was left between each two experimental units as guard area to avoid the overlapping foliar sprayed.

The agricultural practices concerning cultivation, irrigation, fertilization and insect and disease control were conducted according to the recommendation by the Ministry of Agriculture for strawberry commercial production.

\section{Data Recorded}

A random sample of five plants from each plot was taken after 120 days from transplanting in the two growing seasons for measuring the 
vegetative growth, biochemical and plant water relationships as follows :

1. Plant growth parameters : Plant height and number of leaves/plant, also shoot dry weight/plant was measured using dried fresh shoot / plant at $70{ }^{\circ} \mathrm{C}$ till constant weight

2. Photosynthetic pigments: Disc samples from the fourth upper leaf were randomly taken from every plot and determine chlorophyll $a, b,(a+b)$ and carotenoides in both seasons, according to the method described by Wettestein (1957).

3. Percentages and Uptake of $\mathbf{N}, \mathbf{P}$ and $\mathbf{K}$ in shoot: Total Nitrogen, phosphorus and potassium percentages in wet digestion of dried shoots were determined according to the methods described by A.O.A.C. (1995), then uptake of $\mathrm{N}, \mathrm{P}$ and $\mathrm{K}$ by shoots was calculated.

\section{Yield and its Components}

The early yield was determined as weights of all harvested fruits from each plot during January and February months, and then early yield per feddan was calculated. Total yield was recorded from each plot all over the harvested season up to the mid of May, then total yield per feddan was calculated.

For physical and chemical fruit quality, a random samples of ten fruits were taken from each experimental unit at the peak of fruiting to determine average fruit weight. Fruit firmness was determined using Chatillon Penetrometer (N,4, USA) with a needle $3 \mathrm{~mm}$ in diameter, total sugars (\%) were determined as described by Forsee (1938), total soluble solids contents (TSS \%) were determined by using the hand refractometer. Vitamin C was determined according to the method described by A.O.A.C. (1995) and anthocyanin content was determined according the method described by (Geza, et al., 1984).

Statistical analysis: Recorded data were subjected to the statistical analysis of variance according to Snedecor and Cochran (1980) and means separation were done according to LSD at $5 \%$ level.

\section{RESULTS AND DISCUSSION}

\section{Vegetative growth}

Results in Table 1 show that, vegetative growth of strawberry plant expressed in plant height and number of leaves/plant was significantly improved in response to foliar application of cinnamon, chili pepper, henna and turmeric extracts at different rates comparing with the control treatment in both seasons. Plants received $2 \mathrm{~g} / \mathrm{l}$ henna or turmeric extracts recorded the tallest plants and highest number of leaves/ plant with no significant differences between them in both seasons. On the other hand, the shortest 
Table 1: Effect of foliar spray with some natural extracts on plant growth of strawberry after 120 days from transplanting during of 2011/2012 and 2012/2013 seasons

\begin{tabular}{|c|c|c|c|c|}
\hline $\begin{array}{c}\text { Natural extracts } \\
\text { treatments }\end{array}$ & $\begin{array}{c}\text { Plant } \\
\text { height } \\
\text { (cm) }\end{array}$ & $\begin{array}{c}\text { Leaves } \\
\text { number/ } \\
\text { Plant }\end{array}$ & $\begin{array}{l}\text { Shoot dry } \\
\text { weight } \\
(\text { gm) }\end{array}$ & $\begin{array}{c}\text { Relative } \\
\text { increases in } \\
\text { shoot dry } \\
\text { weight \% }\end{array}$ \\
\hline & \multicolumn{4}{|c|}{ 2011/2012 Season } \\
\hline Control ( water) & 14.15 & 9.67 & 8.68 & 00.00 \\
\hline Cinnamon at $1 \mathrm{~g} / \mathrm{l}$ & 17.61 & 13.36 & 11.11 & 28.00 \\
\hline Cinnamon at $2 \mathrm{~g} / \mathrm{l}$ & 17.14 & 14.70 & 11.31 & 30.30 \\
\hline Chili pepper at $1 \mathrm{~g} / \mathrm{l}$ & 14.71 & 11.69 & 10.00 & 15.21 \\
\hline Chili pepper at $2 \mathrm{~g} / \mathrm{l}$ & 14.96 & 12.59 & 11.08 & 27.65 \\
\hline Henna & 17.19 & 15.26 & 12.18 & 40.32 \\
\hline Henna & 19.06 & 16.42 & 12.57 & 44.82 \\
\hline Turmeric & 17.92 & 15.76 & 12.54 & 44.47 \\
\hline Turmeric & 19.65 & 17.12 & 12.85 & 48.04 \\
\hline \multirow[t]{2}{*}{ LSD at $5 \%$ level } & 1.54 & 1.48 & 1.65 & -- \\
\hline & \multicolumn{4}{|c|}{ 2012/2013 Season } \\
\hline Control ( water) & 14.05 & 10.60 & 10.15 & 00.00 \\
\hline Cinnamon at $1 \mathrm{~g} / \mathrm{l}$ & 16.77 & 13.41 & 11.93 & 17.54 \\
\hline Cinnamon at $2 \mathrm{~g} / \mathrm{l}$ & 17.66 & 13.87 & 12.42 & 22.36 \\
\hline Chili pepper at $1 \mathrm{~g} / \mathrm{l}$ & 15.25 & 13.20 & 10.95 & 07.88 \\
\hline Chili pepper at $2 \mathrm{~g} / \mathrm{l}$ & 15.94 & 13.10 & 11.65 & 14.78 \\
\hline Henna & 15.62 & 16.19 & 13.28 & 30.84 \\
\hline Henna & 18.16 & 15.93 & 13.92 & 37.14 \\
\hline Turmeric & 17.33 & 16.25 & 13.69 & 34.88 \\
\hline Turmeric at $2 \mathrm{~g} / \mathrm{l}$ & 19.05 & 16.38 & 14.09 & 38.82 \\
\hline LSD at $5 \%$ level & 1.37 & 1.29 & 1.47 & -- \\
\hline
\end{tabular}

Natural extracts; i.e., cinnamon, chili pepper, henna and turmeric obtained from cinnamon bark, chili pepper fruits, henna leaves and turmeric rhizome, respectively.

plants and lowest number of leaves were recorded by plants sprayed with water only in both seasons.

The essential roles of natural extracts on stimulating cell division, the biosynthesis of organic foods and the resistance of plants to all stresses (Paik and Chung, 1997) could explain the present results.

\section{Dry shoot weight:}

Such data in Table 1 reveal that, foliar spraying with different natural extracts had significant improve of dry shoot weight / plant of strawberry during both seasons under sandy soil condition. Sprayed strawberry plants with 1 or $2 \mathrm{~g} / 1$ of henna or turmeric extracts significantly increased shoot 
dry weight as compared to other treatments in both seasons. The relative increase in shoot dry weight/ plant was about 40.32 and $30.84 ; 44.82$ and $37.14 ; 44.47$ and 34.88 , and 48.04 and $38.82 \%$ than control treatment for henna or turmeric extracts at 1 or $2 \mathrm{~g} / \mathrm{l}$ of each in the $1^{\text {st }}$ and $2^{\text {nd }}$ seasons, respectively. On the other side, sprayed plants with cinnamon extract at $2 \mathrm{~g} / \mathrm{l}$ gave intermediate values followed by chili extract treatment at the same rate in both seasons.

The stimulative effect of foliar spray with chili pepper, cinnamon, henna and turmeric extracts on growth of strawberry compared to control may be due to that cinnamon, henna, chili pepper and turmeric contains minerals like $\mathrm{Ca}, \mathrm{Cu}, \mathrm{P}, \mathrm{K}, \mathrm{Zn}, \mathrm{Mg}, \mathrm{Fe}$ and $\mathrm{Mn}$ and also, contains vitamins 9B1, B6 and C). Zn plays an important role in the metabolic pathway form tryptophane to IAA (Takaki and Kushizahi 1977). Vitamin C plays a considerable role in plant physiology and growth as antioxidants, protection of chloroplast, electron transport system, and many enzymes activities ( Oertli, 1987).

These results agree with Chandrasekaran et al. (2000) on soybean, Hanafy et al. (2012) on Schefflera arboricola regarding henna extract effect and Ahmed et al. (2013) on orange trees regarding turmeric extract.

\section{Leaf pigments}

It is clear from the data in Table (2) that, supplying the plants with natural extracts was significantly enhanced the leaf pigments i.e., chlorophyll a, total chlorophyll and carotenoides contents in leaf as compared to unsprayed plants in both seasons. The promotion was significantly depended on using henna or turmeric extract. The maximum values were recorded on the plants that received turmeric extract at 1 or 2 $\mathrm{g} / \mathrm{l}$ in both seasons. Nevertheless, sprayed plants with turmeric extract at 2 $\mathrm{g} / \mathrm{l}$ recorded increases in total chlorophyll of 19.52 and $18.94 \%$ over unsprayed plants in the $1^{\text {st }}$ and $2^{\text {nd }}$ seasons, respectively. The minimum values were recorded with untreated plants. These results were true during both seasons.

The simulative effect of foliar spray with chili pepper, cinnamon, henna and turmeric extracts compared to control on concentration of chlorophyll $\mathrm{a}, \mathrm{b}$ total and carotenoides in leaf tissues of strawberry may be due to that those extracts contains magnesium element which has a considerable role in generation of the chlorophyll molecule (Marschner, 1995).

These results are agreement with those reported with Pathak and Srivastava (2000) on sunflower. 
Table 2: Effect of foliar spray with some natural extracts on photosynthetic pigments $(\mathrm{mg} / \mathrm{g} \mathrm{DW})$ in strawberry leaf tissues after 120 days from transplanting, during of $2011 / 2012$ and 2012/2013 seasons.

\begin{tabular}{|c|c|c|c|c|}
\hline $\begin{array}{c}\text { Natural extracts } \\
\text { treatments }\end{array}$ & $\begin{array}{c}\text { Chlorophyll } \\
\text { a }\end{array}$ & $\begin{array}{c}\text { Chlorophyll } \\
\text { b }\end{array}$ & $\begin{array}{c}\text { Total Chl. } \\
(\mathbf{a}+\mathbf{b})\end{array}$ & Carotenodes \\
\hline & \multicolumn{4}{|c|}{ 2011/2012 Season } \\
\hline Control ( water) & 2.70 & 1.96 & 4.66 & 2.03 \\
\hline Cinnamon & 2.89 & 2.11 & 5.00 & 2.00 \\
\hline Cinnamon at $2 \mathrm{~g} / \mathrm{l}$ & 2.98 & 2.17 & 5.15 & 2.01 \\
\hline Chili pepper at $1 \mathrm{~g} / \mathrm{l}$ & 2.74 & 2.00 & 4.74 & 2.37 \\
\hline Chili pepper at $2 \mathrm{~g} / \mathrm{l}$ & 2.81 & 2.05 & 4.86 & 2.26 \\
\hline Henna & 3.05 & 2.26 & 5.31 & 2.34 \\
\hline Henna & 3.12 & 2.31 & 5.43 & 2.37 \\
\hline Turmeric & 3.22 & 2.34 & 5.57 & 2.42 \\
\hline Turmeric & 3.16 & 2.41 & 5.57 & 2.33 \\
\hline LSD at $5 \%$ level & 0.14 & NS & 0.29 & 0.18 \\
\hline & \multicolumn{4}{|c|}{ 2012/2013 Season } \\
\hline Control (water) & 2.86 & 2.05 & 4.91 & 1.97 \\
\hline Cinnamon & 2.99 & 2.17 & 5.16 & 2.00 \\
\hline Cinnamon & 3.04 & 2.23 & 5.27 & 1.93 \\
\hline Chili pepper at $1 \mathrm{~g} / \mathrm{l}$ & 2.88 & 2.01 & 4.89 & 2.10 \\
\hline Chili pepper at $2 \mathrm{~g} / \mathrm{l}$ & 2.89 & 2.08 & 4.97 & 2.17 \\
\hline Henna & 3.14 & 2.33 & 5.47 & 2.23 \\
\hline Henna & 3.31 & 2.38 & 5.69 & 2.32 \\
\hline Turmeric & 3.35 & 2.42 & 5.77 & 2.43 \\
\hline Turmeric & 3.39 & 2.46 & 5.84 & 2.38 \\
\hline LSD at $5 \%$ level & 0.16 & NS & 0.26 & 0.22 \\
\hline
\end{tabular}

Natural extracts ; i.e., cinnamon, chili pepper, henna and turmeric obtained from cinnamon bark, chili pepper fruits, henna leaves and turmeric rhizome, respectively.

\section{Mineral and uptake of $N, P$ and $K$ in shoot:}

It is evident from the data in Table 3 that, spraying strawberry plants with cinnamon, chili, henna and turmeric at different rates had significant effect on mineral and uptake of $\mathrm{N}, \mathrm{P}$ and $\mathrm{K}$ in shoot as compared to unsprayed plants during the two growing seasons. N,P and $\mathrm{K}$ contents and uptake in shoots significantly affected by sprayed plants with henna or turmeric extracts at different rates as compared to cinnamon or chili. The maximum $\mathrm{N}, \mathrm{P}$ and $\mathrm{K}$ contents and uptake by shoots were recorded with the 
Table 3: Effect of foliar spray with some natural extracts on the N,P and $\mathrm{K}$ contents and uptake in shoots of strawberry after 120 days from transplanting, during 2011/2012 and 2012/2013 seasons.

\begin{tabular}{|c|c|c|c|c|c|c|}
\hline \multirow{2}{*}{$\begin{array}{c}\text { Natural extracts } \\
\text { treatments }\end{array}$} & \multicolumn{3}{|c|}{$\begin{array}{c}\text { Mineral contents } \\
(\%)\end{array}$} & \multicolumn{3}{|c|}{$\begin{array}{c}\text { Mineral uptake } \\
(\mathrm{mg} / \mathrm{shoot})\end{array}$} \\
\hline & $\mathbf{N}$ & $\mathbf{P}$ & $\mathbf{K}$ & $\mathbf{N}$ & $\mathbf{P}$ & $\mathbf{K}$ \\
\hline & \multicolumn{6}{|c|}{ 2011/2012 Season } \\
\hline Control ( water) & 2.55 & 0.410 & 1.40 & 221.34 & 35.62 & 121.71 \\
\hline Cinnamon at $1 \mathrm{~g} / \mathrm{l}$ & 2.83 & 0.479 & 1.63 & 314.41 & 53.19 & 181.12 \\
\hline Cinnamon at $2 \mathrm{~g} / \mathrm{l}$ & 2.86 & 0.490 & 1.70 & 323.47 & 55.44 & 192.11 \\
\hline Chili pepper at $1 \mathrm{~g} / \mathrm{l}$ & 2.67 & 0.433 & 1.45 & 267.00 & 43.32 & 144.78 \\
\hline Chili pepper at $2 \mathrm{~g} / \mathrm{l}$ & 2.74 & 0.467 & 1.56 & 303.59 & 51.79 & 173.05 \\
\hline Henna & 2.92 & 0.490 & 1.77 & 355.66 & 59.71 & 215.22 \\
\hline Henna & 3.20 & 0.513 & 1.93 & 402.24 & 64.48 & 242.17 \\
\hline Turmeric & 3.08 & 0.502 & 1.89 & 386.23 & 62.90 & 237.31 \\
\hline Turmeric & 3.25 & 0.524 & 1.94 & 417.63 & 67.39 & 249.03 \\
\hline LSD at $5 \%$ level & 0.26 & 0.032 & 0.21 & 28.29 & 5.68 & 22.28 \\
\hline & \multicolumn{6}{|c|}{ 2012/2013 Seasons } \\
\hline Control ( water) & 2.69 & 0.456 & 1.43 & 273.08 & 46.28 & 144.64 \\
\hline Cinnamon at $1 \mathrm{~g} / \mathrm{l}$ & 3.06 & 0.456 & 1.53 & 364.49 & 54.40 & 182.24 \\
\hline Cinnamon & 3.14 & 0.479 & 1.62 & 389.37 & 59.47 & 201.05 \\
\hline Chili pepper at $1 \mathrm{~g} / \mathrm{l}$ & 2.72 & 0.433 & 1.44 & 298.34 & 47.44 & 157.29 \\
\hline Chili pepper at $2 \mathrm{~g} / \mathrm{l}$ & 2.87 & 0.445 & 1.43 & 334.68 & 51.80 & 166.01 \\
\hline at $1 \mathrm{~g} / \mathrm{l}$ & 3.20 & 0.490 & 1.70 & 425.41 & 65.10 & 225.57 \\
\hline at $2 \mathrm{~g} / \mathrm{l}$ & 3.33 & 0.513 & 1.81 & 463.37 & 71.41 & 252.31 \\
\hline Turmeric & 3.27 & 0.490 & 1.72 & 447.91 & 67.11 & 235.66 \\
\hline Turmeric & 3.34 & 0.524 & 1.97 & 470.63 & 73.89 & 277.88 \\
\hline LSD at $5 \%$ level & 0.42 & 0.041 & 0.24 & 24.19 & 7.18 & 29.17 \\
\hline
\end{tabular}

Natural extracts ; i.e., cinnamon, chili pepper, henna and turmeric obtained from cinnamon bark, chili pepper fruits, henna leaves and turmeric rhizome, respectively.

highest rate of henna or turmeric. Moreover, application of $2 \mathrm{~g} / \mathrm{l}$ turmeric extract recorded 3.25 and $3.34 \%$ of N, 0.524 and $0.524 \%$ of $\mathrm{P}$ and 1.94 and $1.97 \%$ of $\mathrm{K}$ in shoots and in the $1^{\text {st }}$ and $2^{\text {nd }}$ seasons, respectively. Also, this treatment recorded the maximum values of $\mathrm{N}, \mathrm{P}$ and $\mathrm{K}$ uptake by shoot 417.63 and 470.63 of $\mathrm{N}$ uptake, 67.39 and 73.89 of $\mathrm{P}$ uptake and 249.03 and $277.88 \mathrm{mg} / \mathrm{shoot}$ of $\mathrm{K}$ uptake in the first and second seasons, respectively. 
Henna leaf powder contains $\mathrm{Ca}, \mathrm{Na}, \mathrm{P}$ and $\mathrm{K}$ ranging from 0.2 to $4 \%$. The $\mathrm{Mg}$ content was less than $2 \%$, while $\mathrm{Cu}, \mathrm{Zn}$ and $\mathrm{Fe}$ contents were above $0.5,1.1$ and $15 \%$, respectively, Mn contents was less than $1.5 \%$ while $\mathrm{N}$ content was less than $1.5 \%$ (Zumrutal and Ozaslan, 2012).

These results are agreement with those reported with Hanafy et al. (2012) on Schefflera arboricola and Ahmed et al. (2013) on Valencia orange.

\section{Yield and its components:}

Early and total yield per feddan were significantly increased with sprayed strawberry plants with natural extracts of cinnamon, chili pepper, henna and turmeric extracts at different rates as compared to control treatment in both seasons (Table 4).

As for early yield /feddan, treated plants with henna or turmeric extracts at $2 \mathrm{~g} / \mathrm{l}$ had significant effect on early yield /feddan as compared to the rest treatments of foliar sprays in both seasons. Moreover, the highest early yield feddan was obtained from spraying plants with $2 \mathrm{~g}$ turmeric extract of one liter water in both seasons. The relative increases in early yield/fed. were about 32.51 and $32.07 \%$ for henna extract at or $2 \mathrm{~g} / \mathrm{l}$ and 32.97 and $37.45 \%$ for turmeric extract at $2 \mathrm{~g} / \mathrm{l}$ than control treatment in the $1^{\text {st }}$ and $2^{\text {nd }}$ seasons, respectively.

Regarding total yield /feddan, the data in Table 4 showed that, application of different extracts to strawberry plants had significant effect on total yield/feddan than control treatment in both seasons.

Sprayed plants with turmeric extract at $2 \mathrm{~g} / 1$ was significantly increased total yield/feddan with insignificant differences with henna extract at $2 \mathrm{~g} / \mathrm{l}$. as compared to other foliar spray treatments. Moreover, the highest rate of these extracts were more effective than the low rates. Treated plants with henna extract came in the second rank, while cinnamon extract recorded intermediate values. On the other hand, chili pepper extract gave the lowest values compared to other extracts in both seasons. The relative increases in total yield were about 11.40 and $13.95 \%$ for henna extract at 2 $\mathrm{g} / \mathrm{l}$ and 13.08 and $16.59 \%$ for turmeric extract at $2 \mathrm{~g} / \mathrm{l}$ in the $1^{\text {st }}$ and $2^{\text {nd }}$ seasons, respectively than control treatment.

The great benefits of these plant extracts on the yield were mainly attributed to their positive action on enhancing growth and nutritional status of the plants in favour of producing higher fruit weight.

These results are in harmony with those obtained by Mohamed and Mohammed (2013) on date palms and Ahmed et al. (2014) on yield of Keitte mango trees were obtained due to spraying the trees three times with 
Table 4: Effect of foliar spray with some natural extracts on yield and its components of strawberry plants during 2011/2012 and 2012/2013 seasons.

\begin{tabular}{|c|c|c|c|}
\hline $\begin{array}{l}\text { Natural extracts } \\
\text { treatments }\end{array}$ & $\begin{array}{c}\text { Early yield } \\
\text { ( ton/fed.) }\end{array}$ & $\begin{array}{l}\text { Total yield } \\
\text { (ton/fed.) }\end{array}$ & $\begin{array}{c}\text { Relative } \\
\text { increases in } \\
\text { total yield (\%) }\end{array}$ \\
\hline & \multicolumn{3}{|c|}{ 2011/2012 Seasons } \\
\hline Control ( water) & 3.848 & 17.308 & 00.00 \\
\hline Cinnamon at $1 \mathrm{~g} / \mathrm{l}$ & 4.425 & 18.740 & 08.27 \\
\hline Cinnamon at $2 \mathrm{~g} / \mathrm{l}$ & 4.454 & 18.891 & 09.15 \\
\hline Chili pepper at $1 \mathrm{~g} / \mathrm{l}$ & 4.035 & 18.353 & 06.04 \\
\hline Chili pepper at $2 \mathrm{~g} / \mathrm{l}$ & 4.184 & 18.584 & 07.37 \\
\hline Henna & 4.589 & 18.863 & 08.98 \\
\hline Henna & 5.099 & 19.281 & 11.40 \\
\hline Turmeric & 4.865 & 19.128 & 10.52 \\
\hline Turmeric & 5.117 & 19.572 & 13.08 \\
\hline LSD at $5 \%$ level & 0.275 & 0.680 & --- \\
\hline & \multicolumn{3}{|c|}{ 2012/2013 Seasons } \\
\hline Control ( water) & 3.716 & 17.066 & 00.00 \\
\hline Cinnamon at $1 \mathrm{~g} / \mathrm{l}$ & 4.142 & 18.792 & 10.11 \\
\hline Cinnamon & 4.524 & 19.278 & 12.96 \\
\hline Chili pepper at $1 \mathrm{~g} / \mathrm{l}$ & 3.936 & 18.740 & 09.81 \\
\hline Chili pepper at $2 \mathrm{~g} / \mathrm{l}$ & 4.055 & 18.821 & 10.28 \\
\hline Henna & 4.566 & 18.629 & 09.16 \\
\hline Henna & 4.908 & 19.446 & 13.95 \\
\hline Turmeric & 4.787 & 18.752 & 09.88 \\
\hline Turmeric & 5.108 & 19.898 & 16.59 \\
\hline LSD at $5 \%$ level & 0.203 & 0.595 & -- \\
\hline
\end{tabular}

turmeric extract at $0.1 \%$ as compared to onion oil, garlic oil and green tea extract.

\section{Physical fruit characters}

Data in Table 5 indicate that, all treatments of foliar spray with natural extracts to strawberry plants had significant effect on average fruit weight and fruit firmness than control treatment in both seasons. 
Table 5: Effect of foliar spray with some natural extracts on some fruit physical characters of strawberry plants during $2011 / 2012$ and 2012/2013 seasons.

\begin{tabular}{|c|c|c|c|c|}
\hline \multirow{2}{*}{$\begin{array}{l}\text { Natural extracts } \\
\text { treatments }\end{array}$} & \multicolumn{2}{|c|}{$\begin{array}{l}\text { Average fruit weight } \\
\text { (g) }\end{array}$} & \multicolumn{2}{|c|}{$\begin{array}{r}\text { Firmness } \\
\left(\mathrm{g} / \mathrm{cm}^{2}\right)\end{array}$} \\
\hline & $\begin{array}{c}2011 / 2012 \\
\text { season }\end{array}$ & $\begin{array}{l}2012 / 2013 \\
\text { season }\end{array}$ & $\begin{array}{c}2011 / 2012 \\
\text { season }\end{array}$ & $\begin{array}{c}2012 / 2013 \\
\text { season }\end{array}$ \\
\hline Control ( water) & 26.85 & 25.65 & 105.55 & 103.18 \\
\hline Cinnamon at $1 \mathrm{~g} / \mathrm{l}$ & 28.80 & 27.63 & 125.07 & 125.95 \\
\hline Cinnamon at $2 \mathrm{~g} / \mathrm{l}$ & 30.20 & 29.37 & 131.57 & 128.37 \\
\hline Chili pepper at $1 \mathrm{~g} / \mathrm{l}$ & 27.05 & 26.64 & 109.99 & 110.57 \\
\hline Chili pepper at $2 \mathrm{~g} / \mathrm{l}$ & 27.87 & 26.61 & 118.26 & 117.38 \\
\hline Henna & 30.60 & 30.69 & 140.73 & 140.44 \\
\hline at $2 \mathrm{~g} / \mathrm{l}$ & 32.42 & 32.28 & 142.21 & 147.24 \\
\hline Turmeric & 31.46 & 31.95 & 128.72 & 126.99 \\
\hline Turmeric & 32.66 & 33.29 & 132.76 & 134.92 \\
\hline LSD at $5 \%$ level & 1.25 & 1.16 & 5.98 & 5.04 \\
\hline
\end{tabular}

Natural extracts ; i.e., cinnamon, chili pepper, henna and turmeric obtained from cinnamon bark, chili pepper fruits, henna leaves and turmeric rhizome, respectively.

Regarding average fruit weight, data indicated that, application of henna or turmeric at the highest rate recorded significant increases in weight of fruit as compared to other natural extracts in both seasons. Moreover, the largest weight of fruit (32.66 and $33.29 \mathrm{~g}$ ) was obtained by sprayed plants with turmeric extract at $2 \mathrm{~g} / 1$ in the $1^{\text {st }}$ and $2^{\text {nd }}$ seasons, respectively without insignificant difference with turmeric extract at $1 \mathrm{~g} / 1$ or henna extract at 2 $\mathrm{g} / 1$ in both seasons. On the other hand, the lowest fruit weight was obtained by unsprayed plants $(26.85$ and $25.65 \mathrm{~g})$ in the $1^{\text {st }}$ and $2^{\text {nd }}$ seasons, respectively.

Concerning, fruit firmness data in (Table 5) also showed that, sprayed strawberry plants with henna extract at $2 \mathrm{~g} / 1$ recorded significant increasing in fruit firmness $\left(142.21\right.$ and $\left.147.24 \mathrm{~g} / \mathrm{cm}^{3}\right)$ in the $1^{\text {st }}$ and $2^{\text {nd }}$ seasons, respectively comparing with the other treatments in both seasons.

The stimulative effect of all extracts compared to control may be due to that those extracts contain $\mathrm{Ca}$ element and then increased fruit firmness (Zumrutal and Ozaslan, 2012).

\section{Fruit quality}

Data in Table 6 show that treating strawberry plants with cinnamon, chili, henna and turmeric extracts at different rates were significantly 
Table 6: Effect of foliar spray with some natural extracts on fruit chemical properties of strawberry during $2011 / 2012$ and 2012/2013 seasons

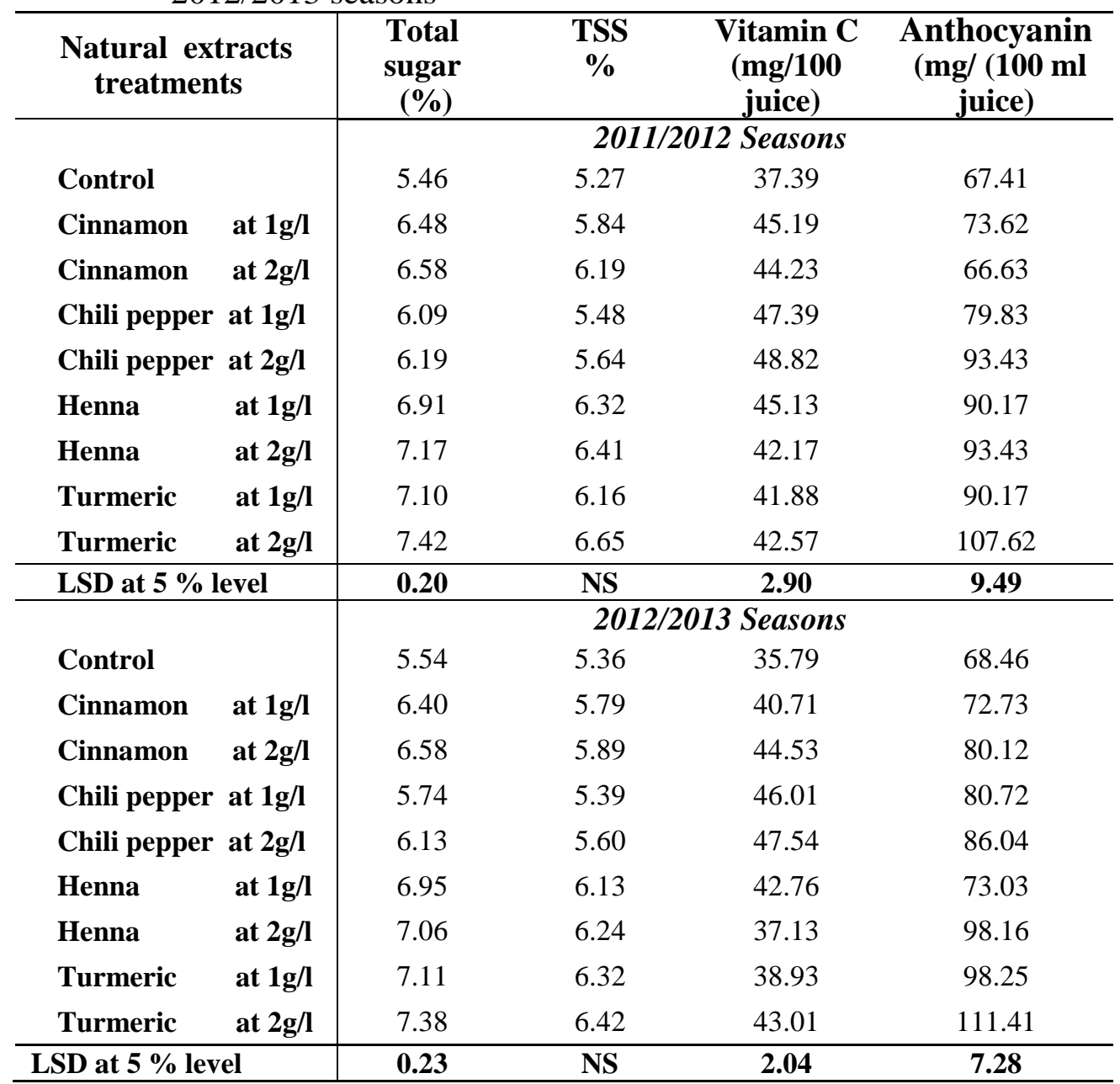

Natural extracts ; i.e., cinnamon, chili pepper, henna and turmeric obtained from cinnamon bark, chili pepper fruits, henna leaves and turmeric rhizome, respectively

improved fruit quality in terms of increasing fruit total sugars, vitamin C content and anthocyanin in relative to the control treatment in both seasons. While these treatments had insignificant effect on TSS in fruits of both seasons.

Using turmeric extract at $2 \mathrm{~g} / \mathrm{l}$ had significant effect on total sugars and anthocyanin pigment in the fruit and recorded the maximum values (7.42 and $7.34 \%$ ) of total sugars and ( 107.62 and $111.41 \mathrm{mg} / 100 \mathrm{ml}$ juice) of anthocyanin pigment in the $1^{\text {st }}$ and $2^{\text {nd }}$ season, respectively followed by 
henna extract at $2 \mathrm{~g} / \mathrm{l}$. . While treated plants with 1 or $2 \mathrm{~g}$ chili pepper extract $/ 1$ recorded the highest contents of vitamin $C$ (48.82 and 47.54 $\mathrm{mg} / 100 \mathrm{ml}$ juice) in the $1^{\mathrm{st}}$ and $2^{\text {nd }}$ seasons, respectively. On the other hand the lowest values of all fruit quality parameters were obtained with unsprayed plants in both seasons.

These results are in agreement with those obtained by Mohamed and Mohammed (2013) on date palm.

Conclusively, from foregoing results of this study, it could be concluded that spraying strawberry plants with $2 \mathrm{~g} / \mathrm{l}$ henna or turmeric extracts were the best treatments for increased plant growth plant growth , total yield and fruit quality of strawberry under sandy soil conditions.

\section{REFERENCES}

Ahmed F.F., A.E.M. Mansour, M.A.A. Montasser, M.A. Merwad and E.A.M. Mostafa 2013. Response of valencia orange trees to foliar application of roselle, turmeric and seaweed extracts. J. Appl. Sci. Res., 9 (1): 960-964.

Ahmed, F.F. , M. Kh. Kamel and H. I.M. Ibrahim 2014. The synergistic effects of using plant extracts and salicylic acid on yield and fruit quality of keitte mango trees. Stem Cell, 5 (2):30-39.

A.O.A.C. Association of Official Agricultural Chemists 1995. Official systems of analysis. $17^{\text {th }}$. Ed. A.O.A.C., Wash., D.C

Banerjee A. and S.S. Nigam 1978 . Antimicrobial efficacy of the essential of Curcuma longa. India J. Med. Res., 68: 864-866.

Chandrasekaran, A., V. Narasimhan and K. Rajappan 2000. Effect of plant extracts, antagonists and chemicals on seedling vigour and anthracnose disease of soybean. International J. Tropical Plant Diseases, 18: 141-146.

Forsee, W. T., Jr.1938. Determination of sugar in plant materials A photometeric method. Indus. Eng. Chem. Anal. Ed., 10:411-418.

Geza, H.; G.F. Parsons and L.R. Mattick 1984. Physiological and biochemical events during development and maturation of grape berries. Am. J. Enol. Vitic., 35 (4): 220 - 227.

Hanafy, M.S., F.M. Saadawy, S.M.N. Milad and R.M. Ali 2012. Effect of some natural extracts on growth and chemical constituents of Schefflera arboricola plants. J. Hort. Sci. and Ornamental Plants, 4 (1): 26-33. 
Jakhetia, V., R. Patel, P. Khatri, N. Pahuja, S. garg, A. Pandey and S. Sharma. 2010. Cinnamon: A Pharamcological Review. J. Adv. Sci. Res., 1 (2): 19-23.

Maas, J.L., S.Y. Wang and G.J. Galletta. 1991. Evaluation of strawberry cultivars for allegic acid content. Hort. Science, 26: 66-68.

Marschner, H. 1995. Mineral Nutrition of Higher Plants. $2^{\text {nd }}$ (ed.), Academic Press Limited, Text Book.

Mohamed, A.Y. and H.H. Mohammed 2013. The synergistic effects of using turmeric with various nutrients on fruiting of Sewy Date palms. Hort. Science J. of Suez Canal Univ., 287-296.

Nizam U., Shaheen, B. S. and S. Begum 2013. Chemical Constituents and Bioactivities of Lawsonia alba Lam. (Henna). J. Chem. Soc. Pak., 35,2:476-485.

Oertli, J.J. 1987. Exogenous application of vitamins as regulators for growth and development of plants. A review. Z. pflanzenernahr. Bodenk., 150: 375-391.

Paik, S. and I. Chung. 1997. Effect of medicinal plant extracts on apple storage disease. Korean J. of Plant Pathology, 13: 57 - 62.

Pathak, D. and M.P. Srivastava, 2000. Effect of fungicides, plant extracts and biocontrol agents on total phenols content of sunflower plants. Annals of Biol., 16: 227-229.

Perez, A.G., R. Olias, J. Espeda, J.M. Olias and C. Sanz. 1997. Rapid determination of sugars, nonvolatile acids and ascorbic acid in strawberry and fruits. J. Agric. Food Chem., 45: 3545-3549.

Ruby, A.J., G. Kuttan and B.K. Dinesh. 1995. Anti-tumour and antioxidant activity of natural curcuminoids. Cancer Lett., 94: 79-83 (1995).

Slim, M.A.F. 2014. Response of valencia orange trees to antioxidants and biofertilization. Ph.D. Thesis, Fac. Environ. Agric. Sciences, El-Arish, SuezCanal University

Snedecor, G.W. and W.G. Cochran 1980. Statistical Methods. $7^{\text {th }}$ ed., Iowa State Univ., Press, Ames., Iowa, U.S.A.

Vangalapati, M. , N. Sree Satya , D.V. Surya Prakash and A. Sumanjali. 2012. A Review on Pharmacological Activities and Clinical effects of Cinnamon Species. Res. J. Pharma. Bio and Chem. 3 (1): 653-663.

Wettestein, D. 1957. Chlorophyll. Lethale under Submikroskopische Formwechsel der Plastiden. Exp. Cell Reso, 12: 427-506. 
Zumrutdal, E. and M. Ozaslan. 2012. A miracle plant for the herbal pharmacy; Henna (Lawsonia inermis). International J. Pharmacology, 8: $483-489$.

تأثير معاملات الرش الورقى ببعض المستخلصات الطبيعية على انتاجية

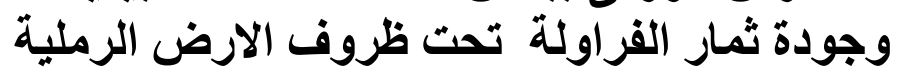

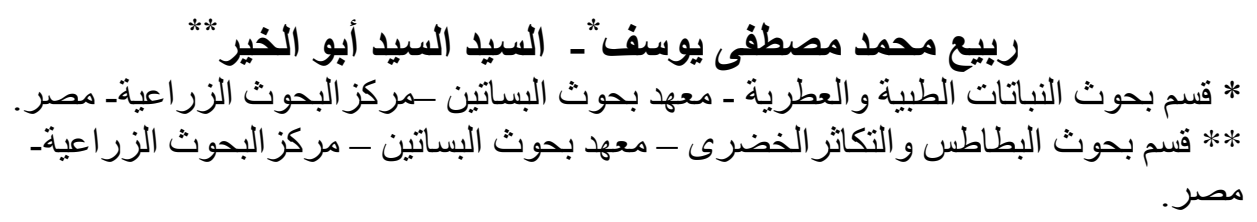

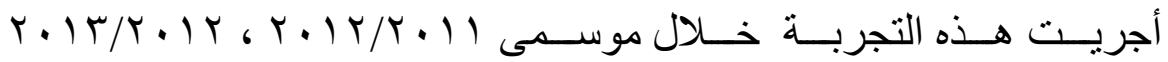

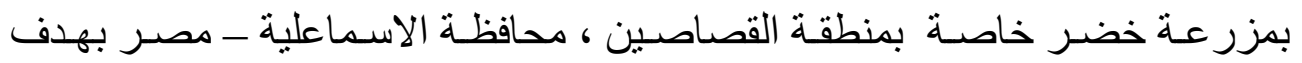

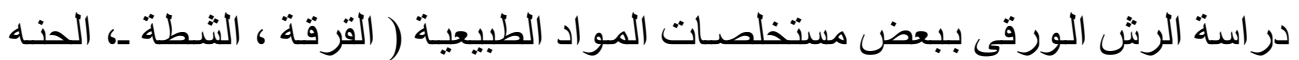

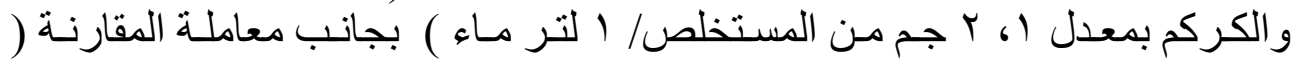

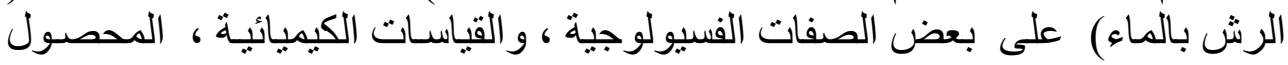

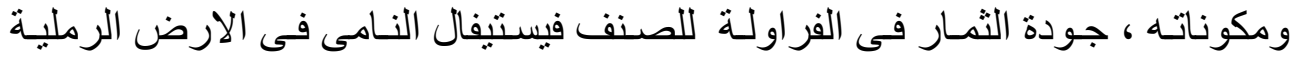

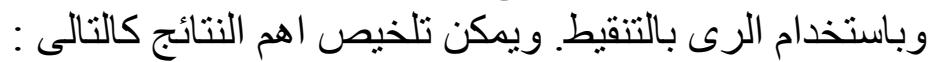

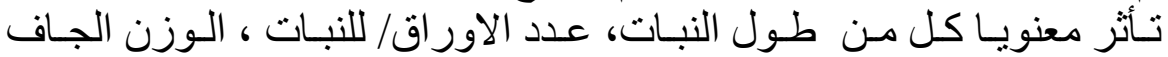

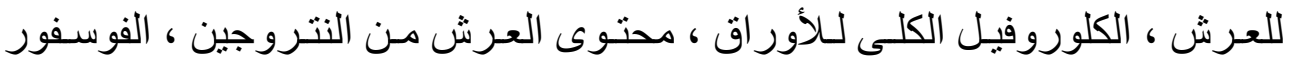

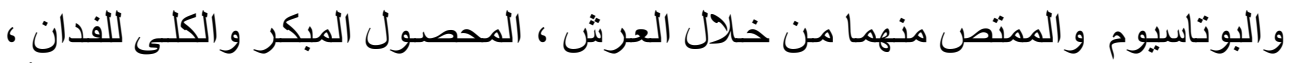

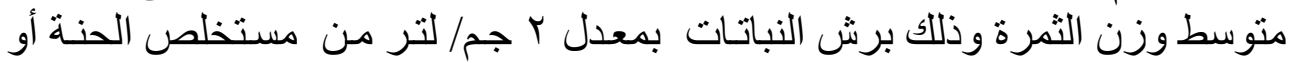

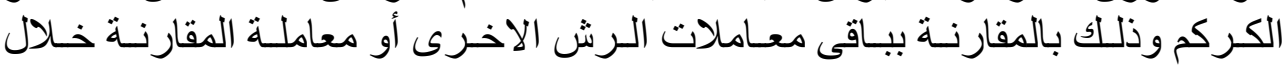

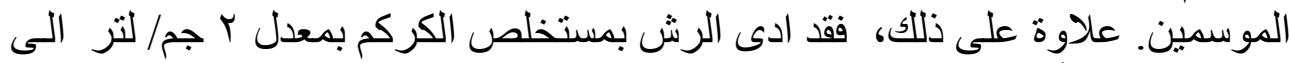

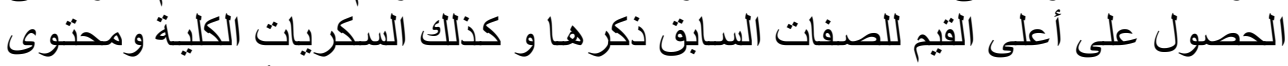

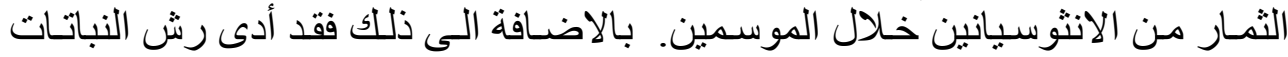

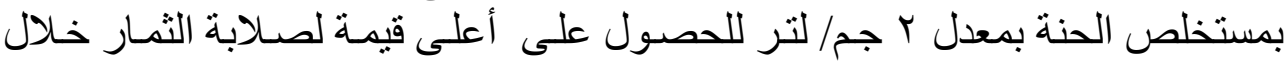

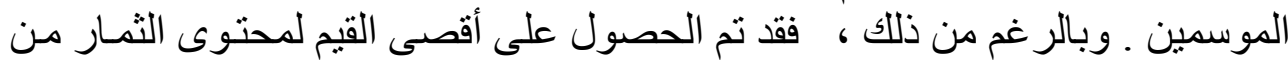

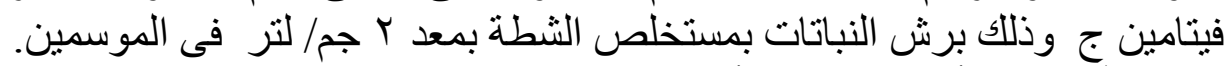

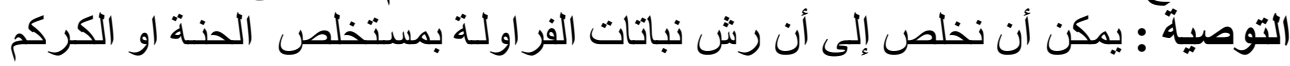

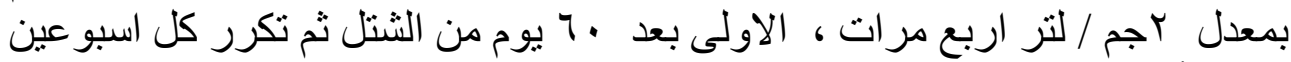

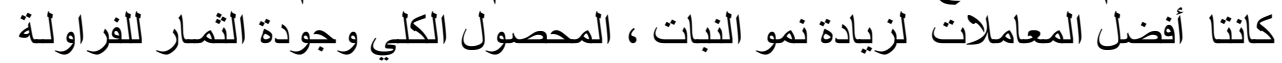
تحت ظروف الارض الرضية. 